\title{
Kehittämisen ja tutkimuksen välitiloja paikantamassa
}

Timo Toikko \& Teemu Rantanen (2008). Tutkimuksellinen kehittämistoiminta. Tampere University Press. $197 \mathrm{~s}$.

$\mathrm{T}_{\mathrm{i}}$ imo Toikko ja Teemu Rantanen tarkastelevat kirjassaan moniulotteisesti heidän tutkimukselliseksi kehittämistoiminnaksi nimeämäänsä tutkimuksen ja kehittämisen muotoa, jolle on tyypillistä se, että käytännön ongelmat ja kysymykset ohjaavat tiedontuotantoa. Kirja sijoittuu ennen kaikkea työelämän kehittämisen alueelle, mutta sen näkökulma on kaikkea muuta kuin kapea. Kirjoittajat käsittelevät monipuolisesti tutkimuksellista kehittämistoimintaa huomioiden sen historialliseen taustaan, toteuttamiseen ja nykytilaan liittyvät seikat. Kirjan nimen perusteella aihepiiriä voisi epäillä liiankin laajaksi, jotta siitä voisi kirjoittaa yhtenäisen kuvauksen, mutta tekijät onnistuvat hahmottamaan moninaista kenttää useasta näkökulmasta ja tuomaan esille tutkimuksellisen kehittämistoiminnan kannalta olennaisia kysymyksiä. Kaiken kaikkiaan kirja jatkaa soveltavan tutkimuksen perusteiden pohdintaa, josta on ilmestynyt muutaman viime vuoden kuluessa useampia julkaisuja. Tässä mielessä se on tärkeä lisä siihen tarkasteluun, josta on kirjoitettu soveltavan tutkimuksen, toimintatutkimuksen tai arviointitutkimuksen nimikkeen alla.

Kirja on suppea kokonaisesitys aihepiiristään, mutta samalla sen sisällölliset teemat ovat yhteisiä tutkimukselliselle kehittämistoiminnalle yleisesti. Liikkeel- le lähdetään kehittämistoiminnan mielekkäästä rajaamisesta ja sen ulottuvuuksista. Sen jälkeen siirrytään kehittämistoiminnan metodologiaan, jossa pohditaan todellisuus- ja tietokäsitykseen, intresseihin ja reflektiivisyyteen liittyviä kysymyksiä. Tästä jatketaan kehittämisprosessin hallintaan, joka on kirjan luvuista sisällöllisesti laajin. Kirjan loppuluvut käsittelevät vielä kehittämistoimintaan osallistumista, tutkimuksellisuutta kehittämistoiminnassa sekä tutkimuksellisen kehittämistoiminnan metodologiaa. Kirja päättyy lukuun, jossa eritellään tiedontuotantoa yhteiskunnallisena toimintana. Näin on tehty retki kehittämistoiminnan teema-alueiden läpi. Tällaisena kirja esittää yleisen kaaren, joka koostuu sellaisenaan melko moniaineksisesta materiaalista mutta jonka kirjoittajat pitävät koossa pohtimalla hieman yleisemmällä tasolla tarkasteltavia asioita.

Kirjan voi nähdä yritykseksi koota laajan joukon tarkasteluita saman linssin alle. Kirjoittavat linjaavat sisältöä siten, että lähtökohtana on ennen muuta suomalainen työelämän tutkimuksellista kehittämistä koskeva keskustelu. Tämä pitää kirjan sisällön kannalta paikkansa, mutta samalla sisältö laajenee kyllä yleisemmäksi tarkasteluksi kehittämisen metodologiasta, sillä tarkastelun ainekset ovat tulleet Suomeenkin maailmalta eli esi- merkiksi arviointi- ja toimintatutkimuksen kautta. Pääosa pohdinnasta sijoittuu lisäksi hyvinvointipalveluiden ja sosiaalialan alueelle, mutta tekijöiden mielestä pohdinta olisi laajennettavissa muiden sektoreiden tarkasteluun. Vaikka kehittämistoiminnan ja tutkimuksen yhdistämisen muodot vaihtelevat, kirjan yleisempi näkökulma antaa aineksia monenlaisen tutkimuksellisen kehittämistoiminnan reflektointiin. Oma paikkansa tällaisella tarkastelulla olisi erityisesti kauppatieteellisessä tutkimuksessa.

Kiinnostavin osa kirjasta liittyy metodologisiin pohdintoihin. Kirjoittajien lähtökohtana on se, että kehittämistoiminta olisi nähtävä ennen kaikkea eri toimijoiden välisenä yhteisenä sosiaalisena toimintana, johon viittaa luonnollisesti jo osallisuuden ja osallistumisen keskeisyys sekä monien osapuolien mukanaolo. Toiminta- ja arviointitutkimuksen kentällä näitä metodologisia kysymyksiä on jo pohdittu pitkään. Kirjoittajat viittaavatkin siihen ja jäsentävät kehittämistoimintaa käyttökelpoisuuden näkökulmasta. Vaikka tutkimuksella on erilainen rooli kehittämistoiminnassa perustutkimukseen verrattuna, myös sitä voidaan nimittäin eritellä Toikon ja Rantasen mukaan luotettavuuden eri kriteereillä. Tärkeä metodologinen avaus kirjassa liittyy lisäksi siihen, että tekijät jäsentävät tutkimuksen paikkaa kehittämistoiminnassa pohtimalla käsitemäärittelyyn, toimintaympäristön kuvaukseen, toteutukseen ja vaikuttavuuteen liittyviä ky- 
symyksiä. Kaikkien osa-alueiden yhteydessä tekijät esittävät havainnollistavia jäsennyksiä, jotka purkavat tiedontuotantoon liittyviä puolia.

Kaiken kaikkiaan Toikon ja Rantasen kirja on sisältää runsaasti ajankohtaista aineistoa työelämän tutkimuksesta ja kehittämisestä. Monessa kohtaa kirjaa tulee mieleen se, että tietystä näkökulmasta olisi kiinnostavaa tietää enemmän tai että olisi paikallaan lukea enemmän tiettyyn teema-alueeseen liittyvästä keskustelusta. Tässä mielessä kirja toimiikin ehkä parhaiten tietynlaisena matkaoppaana ja jäsennysvälineenä tutkimuksellisen kehittämistoiminnan monimutkaiseen maastoon. Kirjassa esitetyt näkökulmat, käsitteet ja erilaiset sisällölliset jäsennykset tarjoavat työelämän tutkijoille ja kehittäjille työkaluja oman toimintansa hahmottamiseen. Teoksen perusteella saa viitteitä tietyistä käytännön tekniikoista, joita voi käyttää hyödyksi tutkimuksen ja kehittämisprosessin roolin paikantamisessa tietyssä hankkeessa. Runsaat lähdeviitteet opastavat puolestaan ottamaan laajemmin selvää siitä, millaiseen ajatteluun erilaiset näkökulmat perustuvat. Tällainen kaksitasoinen puoli voi tuntua aluksi hieman raskaalta aihepiiriä vähemmän tuntevalle, mutta sopii ennen muuta työelämätutkimusta aloittavalle tai sitä jo tekevälle tutkijalle ja kehittäjälle. Kirjan monet taulukot ja kuviot havainnollistavat tutkimuksellisen kehittämistoiminnan eri ulottuvuuksia selkeällä tavalla.

Kirjan luettuaan jää pohtimaan sitä, miksi erilaiset osallistavat tutkimus- ja kehittämismenetelmät ovat tulleet jäädäkseen työelämätutkimukseen. Esimerkiksi taloustieteellisen tarkastelun näkökulmasta selitys löytyy uudenlaisesta postfordistisesta tuotannosta: kapitalistisen tuotannon nykyinen muoto edellyttää tietämiseen ja tietoon perustuvaa orientaatiota. Vanha tayloristinen orientaatio, jossa työntekijä tekee työtä yksin, ei enää sovellu työn ja tuotannon pohjaksi. Tästä näkökulmasta tutkimuksellisella kehittämistoiminnalla pyritään hyödyntämään tietoa, parantamaan työtekijöiden välistä kommunikaatiota ja ottamaan elävän pääoman tietokyvyt käyttöön. Loppujen lopuksi tämä on myös käytännön tasolla erilaisten tekniikoiden perustavoite: tehdä tieto näkyväksi, jakaa se mahdollisimman laajasti toimijoiden välillä ja edesauttaa tiedon yhteistä tuottamista organisaation sisällä. Siksi tämäkään kirja ei varmasti jää millään muotoa viimeiseksi julkaisuksi tästä teema-alueesta. Toivoa samalla sopii, että nimenomaan Toikon ja Rantasen edustama metodologinen tarkastelu kehittämistoiminnasta lisääntyisi. Se antaa välineitä jäsentää tutkimuksellisen kehittämistoiminnan moninaista kenttää, ja auttaa myös varmasti hahmottamaan soveltavan tiedontuotannon ja perustutkimuksen eroa.

\section{Pekka Kuusela}

Timo Laine ja Anita Malinen (toim. 2009)

\section{ELÄVÄ PEILISALI}

Millaista ohjausta tarvitaan, kun pyritään tukemaan opiskelijan autonomista kehittymistä? Millainen arviointikulttuuri edistäisi tuollaista oppimista? Millaisia valmiuksia hyvä pedagogi tarvitsee? Mitä erityistä liittyy aikuiskouluttajan pedagogiseen opetukseen?

Kirjassa pohditaan moniulotteisesti aikuisen oppimista, tiedon eri kerroksia ja ihmistä oppijana. Kirja tarjoaa uusia näkökulmia aikuisten kanssa pedagogista työtä tekeville sekä suunnittelijoille ja arvioijille.

150 sivua, 25 euroa.

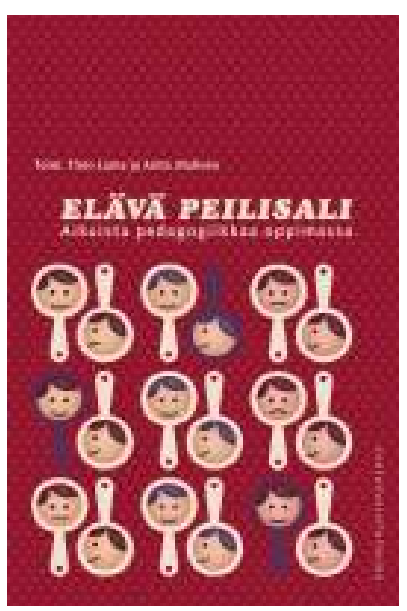

KANSANVALISTUSSEURAN JULKAISUT

verkkokauppa www.kansanvalistus seura.fi tai

info@kvs.fi 